\title{
Training English for Educator at SMP Angkasa, Tuban - Kuta, Bali
}

\author{
Vina Widiadnya ${ }^{1 *}$, Devi Maharani Santika² iD \\ 1,2 Mahasaraswati Denpasar University, Indonesia \\ *Corresponding author: widiadnyana876i@gmail.com
}

\begin{abstract}
This program aims to give English training to Educator at SMP Angkasa, Tuban-Kuta, Bali. In general, the priority problems faced by educators in SMP Angkasa are the low quality of spoken and written English communication in understanding English vocabulary which is often used in the learning process. This is due to a lack of mastery of English vocabulary, lack of understanding of English theory, and lack of motivation to improve their English language skills. Besides that, most of the educators at SMP Angkasa are educators from various disciplines, so mastering English for them is not a priority. The training is focused on providing material on how to communicate well in transferring learning materials to students by communicating in English. Enrich the vocabulary that is often used by educators in the implementation of the teaching and learning process. This community service activities uses methods in the form of application of science and technology with an orientation towards providing English language training and training in communication skills through lectures, demonstrations, and questions and answers. From the English training given to educators at SMP Angkasa, it can be seen that the progressive progress of the trainees towards the use of English for oral and written communication. The progress in communication is evidenced by the use of English when delivering material in class. Furthermore, the ability to listen to the simple spoken conversations of the trainees has also increased, which can be seen during the training. Teachers use full English as the language of instruction during training and trainees can carry out the instructions given at that time well. Finally, there is progress in the ability to read and write simple information from the trainees. This is evidenced by the teaching material prepared by the training participants which is compiled in English and then discussed with the students in their respective classes also in the language of instruction is English.
\end{abstract}

Keywords: Training, Educator, SMP Angkasa

\section{Introduction}

The era of globalization requires every individual to have quality human resources in the mastery of communication and digital. Qualified in mastering English is what is needed in every discipline field. English is an international language that is used even in all parts of the world. English can be seen in all areas of communication, both spoken and written. In Indonesia, English is the first foreign language that must be mastered by the community, especially in the field of education. For this reason, mastery of English and English competency tests are carried out as determinants of student graduation at the high school level.

English is an important communication language needed in the era of 4.1. In the world of education, English is not only a compulsory subject that must be taught to students, but it is also a language requirement for every educator and educational staff to communicate. Educators as a model for their students should know languages and good communication in

$\begin{array}{lll}\text { History: } & & \text { Publisher: Undiksha Press } \\ \text { Received } & : 28 \text { August } 2020 & \text { Licensed: This work is licensed under } \\ \text { Revised } & : \text { 09 September } 2020 & \text { a Creative Commons Attribution 3.0 License } \\ \text { Accepted } & : \text { :06 October } 2020 & \text { : }\end{array}$


delivering messages to others. So, these good things can be imitated and imitated by students and can even be emulated for the community. In oral and written communication, English vocabulary always appears in conversation or some writing. It is undeniable that nowadays, English has a significant influence on every stage of life. In this era of globalization, English has become a means of communication that will always be used intentionally or unintentionally in communication. Messages in social media, in delivering correspondence, even when mentioning certain things, English vocabulary always appears and is often used.

The people have to Improve speaking fluency in English and Indonesian individually, in pairs or groups (Putri., 2019). To become an educator, someone has good language skills to convey information to students and the community. They have been equipped with knowledge in their respective fields and have shared their knowledge with their students, but in the process of sharing the knowledge they already have, English terms often appear in teaching and learning activities. It cannot be denied that educators consciously or unconsciously use these English terms in teaching and learning activities in the classroom. This activity requires educators to understand the meaning and pronunciation in the English terms used.

Some similar service has been carried out before by (Widarwati, 2008) with a program of strengthening English skills for kindergarten teachers in Dukuh Village. By implementing the short course program, it can improve the language skills possessed by the teacher to teach English to his students. Other activities were carried out by (Masruroh et al., 2018) This public service activity is conducted to reduce the errors in early childhood language learning especially related to the teaching techniques and strategies. This activity aims to provide English language teaching training for English teachers in PAUD/TK/MI Abar- Abir Village. Overview of teaching English for the young learners is provided to the teachers. Community service that makes a big contribution to teachers in learning English was also carried out by (Nurdiana \& Rahmawati, 2016) they used effective and efficient learning techniques to increase students' learning outcomes. As a solution to motivate students to learn reading is by providing effective learning techniques. One technique to learn reading is the repeated reading technique. The result of this service is the increasing knowledge of teachers in the repeated reading technique. The teachers can also understand the procedure for using the technique.

In general, the priority problems faced by educators in SMP Angkasa are the low quality of spoken and written English communication in understanding English vocabulary which is often used in the learning process. This is due to a lack of mastery of English vocabulary, lack of understanding of English theory, and lack of motivation to improve their English language skills. Besides that, most of the educators at SMP Angkasa are educators from various disciplines, so mastering English for them is not a priority. This community service activity aims to provide motivation and knowledge about English communication both spoken and written to educators at SMP Angkasa so that it can be used as a means of communication in foreign languages to students both oral and written communication. The objectives of this community service activity are: (1) To improve the ability to communicate orally using English, (2) To improve listening skills to understand simple spoken conversations, (3) To improve the ability to understand reading and write simple information in language English by their respective disciplines. The English training that has been carried out includes providing material such as English vocabulary and expressions used in teaching and learning activities, composing questions and answering sentences, responding to expressions, carrying out communicative conversations using regular and polite language, and other communication techniques that are often used in interaction. The materials given were then packaged by conducting group discussions. 
Problems encountered in SMP Angkasa were then resolved by holding English language training/workshops for educators at SMP Angkasa. The training is focused on providing material on how to communicate well in transferring learning materials to students by communicating in English. Enrich the vocabulary that is often used by educators in the implementation of the teaching and learning process. Ask and answer questions about communication obstacles that have occurred so far as well as inhibiting factors in interacting so that solutions can be found. In addition to enriching vocabulary, educators are taught to use English terms that are often used in the world of education so that they can understand, pronounce, and write English terms following their knowledge discipline properly. Also, educators are taught to communicate by asking and responding in English and communicating verbally or in writing properly and correctly. This can increase the competence of educators in providing learning to their students so that the lessons that are carried out can improve English language skills for both educators and students.

\section{Materials and Methods}

This community service activities uses methods in the form of application of science and technology with an orientation towards providing English language training and training in communication skills through lectures, demonstrations, and questions and answers. This community service was carried out for six months with several stages of activities that have been arranged to make it easier for educators to arrange the schedule of activities between their teaching activities. This activity is carried out from January to June 2020. The stages in the implementation of this community service activity are:

Observation of the problem; carried out before the implementation of training activities begins, problem observation is carried out to determine the problems that have occurred so far and to what extent the training participants have understood basic English which is often used. Lectures are used to convey general knowledge of frequently used English language materials, good and polite vocabulary, and communication techniques. Vocabulary enrichment is more focused on providing educators with a broader understanding of choosing, pronouncing, and writing good and correct English vocabulary. Demonstrations are used to provide direct skills on how to communicate politely in a foreign language. This demonstration method is very effective for training participants to improve their communication skills when transferring their knowledge to their students. Question and answer are used to complement things that have not been accommodated by the two methods above. Questions and answers are also needed to find out some of the obstacles and solutions that have arisen during the ongoing community service at SMP Angkasa. English communication training is carried out according to the schedule given by the principal. This training is aimed at all educators and education personnel at SMP Angkasa, so that after this activity ends, they can understand and improve their English competence and can apply it in educational activities. Final result evaluation

\section{Results and Discussion}

English communication training at SMP Angkasa is one way to improve the language skills possessed by educators to be used as a means of foreign language communication. (Susilofy, 2010) states that student learning activities are all activities that are carried out either physically or spiritually during the learning process. This activity can be the first step for educators in applying international style classes with educators who are equipped with good English communication according to their discipline. The process to determine the level of success of a learning evaluation must certainly be an evaluation. The evaluation in question is about (1) the ability to listen to understand simple spoken conversations, (2) the ability to communicate in English orally (3) the ability to understand reading, and write 
simple information in English according to their respective disciplines (4) Motivate the trainees.

\section{Listening Ability to Understand Simple Spoken Conversations}

In listening activities, trainees are faced with a video recording in English and then try to understand the meaning contained in the video recording.
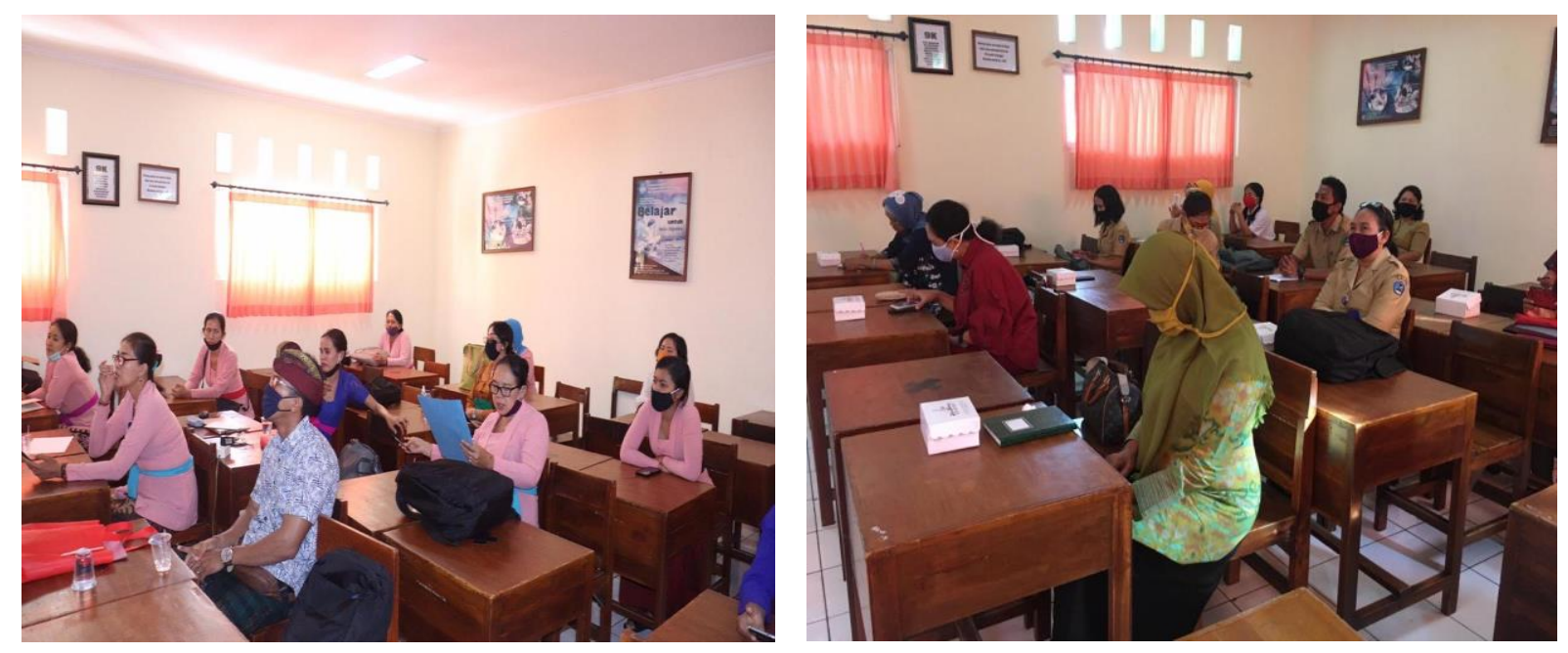

Figure 1. Listening and Understanding the Topics

Things that need to be done in listening activities so that the training participants can easily understand them are:

1. Provides basic understanding to training participants by knowing the meaning of the vocabulary used in the sentences.

2. The training participants are intensified by giving more time to summarize the content of the news delivered.

3. The training participants are trained to listen by recording the information that is being listened to get the main points of the topic being discussed.

4. The videotape given is repeated several times to allow the training participants to properly understand the information discussed.

5. At the end of the listening activity session, the training participants were allowed to discuss vocabulary that was not well understood.

6. Questions are given to the training participants to find out how far they understand the information being listened to.

\section{Ability to Communicate Verbally.}

For educators who are outside the discipline of English, communicating orally in English will be difficult. A functional grammar is functional in various ways. In the first place, it does not consist of a set of rules governing all forms of grammatical structures and their relation to one another, with a concern that they are 'well-formed'. Rather, a functional approach is geared towards meaning and aims to show how meanings are expressed in different forms according to speakers' and writers' communicative goals (Downing, 2015). Several principles can be applied in good and correct spoken English, namely (1) understanding of vocabulary, (2) good and correct pronunciation (3) how to use expressions 
(4) choosing diction (5) level of politeness. The following is an example of a given expression:

Tabel 1. Learning Materials for Angkasa Middle School Educators

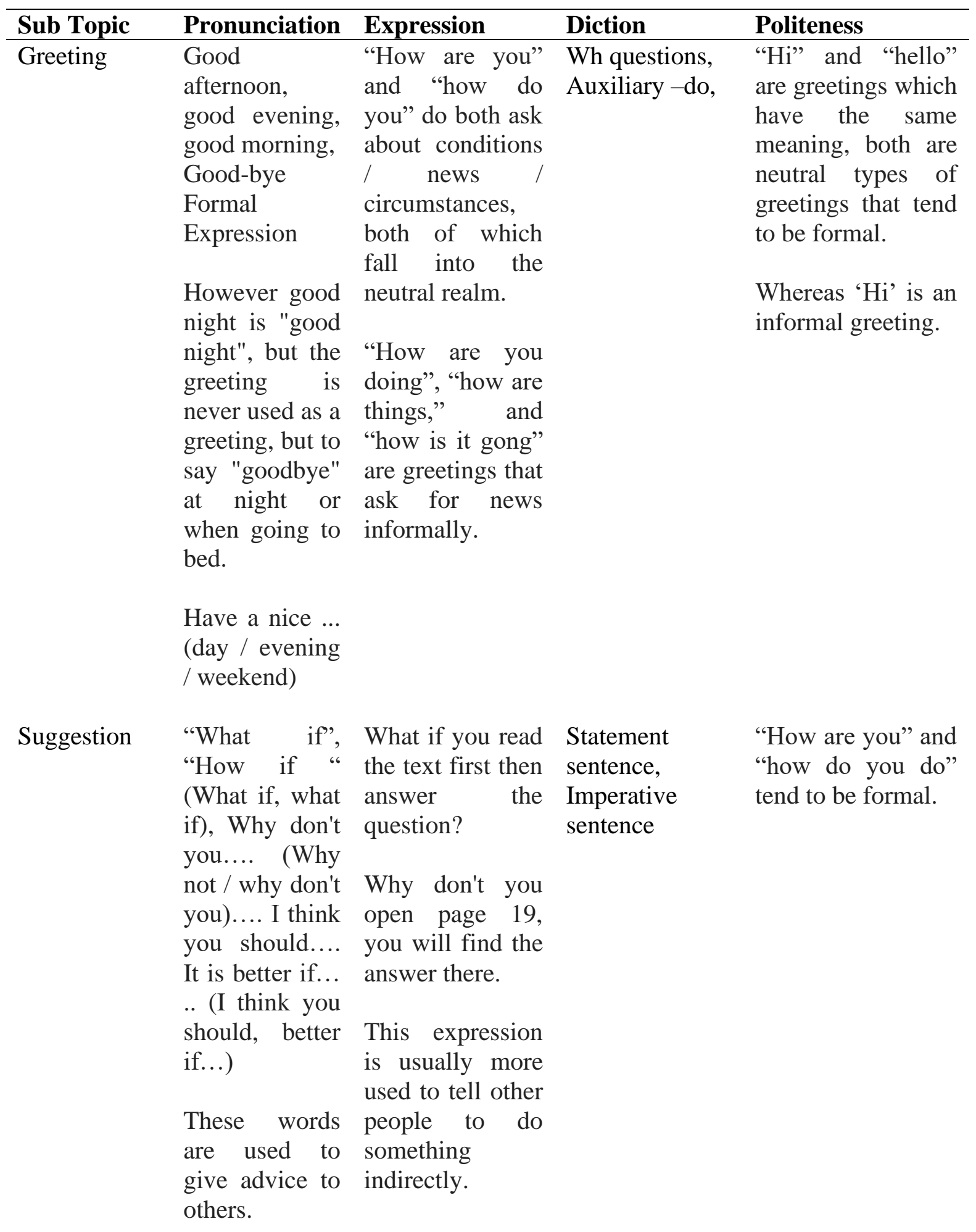

Asking May I, could May I have your Modal/auxiliary More formal words Request you, should I, phone number? verbs, pronouns usually use the could I.... Could you expressions May, I 


\begin{tabular}{|c|c|c|c|c|}
\hline Sub Topic & Pronunciation & Expression & Diction & Politeness \\
\hline & $\begin{array}{l}\text { Requests for } \\
\text { something } \\
\text { from someone } \\
\text { else usually } \\
\text { starts with this } \\
\text { sentence }\end{array}$ & $\begin{array}{l}\text { explain it to me } \\
\text { again? Shall I } \\
\text { repeat my } \\
\text { question? } \\
\text { Expressions can } \\
\text { be used with the } \\
\text { word "please" }\end{array}$ & & $\begin{array}{l}\text { wonder if, or } \\
\text { Could .... Call I } \\
\text { However, this } \\
\text { expression is also } \\
\text { widely used in } \\
\text { informal situations } \\
\text { and can also use } \\
\text { Expression Can i / } \\
\text { you ... }\end{array}$ \\
\hline $\begin{array}{l}\text { Asking } \\
\text { Question }\end{array}$ & $\begin{array}{l}\text { Where is..., } \\
\text { what are..., } \\
\text { how are... For } \\
\text { questions with } \\
\text { question words } \\
\text { like the one } \\
\text { above, the } \\
\text { answer will be } \\
\text { in a long } \\
\text { sentence. Is } \\
\text { he... Are } \\
\text { we...., Would } \\
\text { I... } \\
\text { questions For } \\
\text { without } \\
\text { question words } \\
\text { the answer is } \\
\text { only yes and } \\
\text { no. }\end{array}$ & $\begin{array}{l}\text { Where is your } \\
\text { house, What is } \\
\text { your name, } \\
\text { When will we go } \\
\text { there? The } \\
\text { question word } \\
\text { used in the } \\
\text { question must be } \\
\text { followed by an } \\
\text { auxiliary verb. } \\
\text { As for questions } \\
\text { without the usual } \\
\text { question word, it } \\
\text { will be followed } \\
\text { by a verb-ing or } \\
\text { noun, adverb, } \\
\text { and also an } \\
\text { adjective: Is it } \\
\text { your pen? Are } \\
\text { we going to the } \\
\text { museum? Would } \\
\text { I ask some } \\
\text { questions? }\end{array}$ & $\begin{array}{l}\text { Question words } \\
\text { (5W-1H), to be } \\
\text { (past r and } \\
\text { present), verb- } \\
\text { ing, Word } \\
\text { classes }\end{array}$ & $\begin{array}{l}\text { For the use of } \\
\text { questions in formal } \\
\text { situations using } \\
\text { capital in the past } \\
\text { form such as what } \\
\text { would .., where } \\
\text { could ... How } \\
\text { would } \\
\text { Meanwhile, for } \\
\text { informal the choice } \\
\text { of words is free. }\end{array}$ \\
\hline
\end{tabular}

Grammar is concerned with how sentences and utterances are formed. In a typical English sentence, we can see the two most basic principles of grammar, the arrangement of items (syntax) and the structure of items (morphology) (Swan, 2007). Based on the learning experiences that have been given in this community service, SMP Angkasa educators have understood well the English vocabulary that is often used in teaching and learning activities. The training participants have been able to improve their ability to pronounce the words and sentences that have been given. Given English phrases, they can use it in their daily communication. These expressions can be used in school activities both in classroom learning and even communicating with colleagues.

In order to state general rules about the construction of sentences, it is constantly necessary to refer to smaller units than the sentence itself (Quirk \& Svartvik, 1982). This can be proven by examples of conversations used by trainees who are educators of Biology subject to interact using English during classroom observations: 
Opening the class

Teacher : Good Morning, All. How are you today?

Students : Good morning Ma'am. Good.. Okay...

Teacher : Great.. Now are you ready for the class? Our topic today is Photosynthesis. Why don't you open your book page 25 . You will find about it.

Students : Yes, Ma'am.

Student 1 : Which page should I open, Ma'am

Teacher : Page 25. Have you found it? Shall we read the material together?

Students : Yes, Ma'am.

Closing the class

Teacher : How was it, all? So I can give conclusion that Photosynthesis is important for the plants. And the oxygen as the result from the process is an advantage for human. Now, Do you have any question?

Students : No, Ma'am

Teacher : Ok then, I think that's all for today. I'll see you in the next class.

Students : Thank you Ma'am. Bye

Based on the results of these observations, it can be concluded that after the English communication training was carried out, most of the training participants could confidently carry out the greeting, opening, and closing in English. Provide some terms in biology lessons using English vocabulary.

\section{Ability to Understand Reading and Writing Simple Information}

The ability to understand reading begins with a reading test for the educator, trying to pronounce it well and then understanding the meaning and information contained in each paragraph. This activity is carried out using reading comprehension techniques and requires the trainees to read and find the implied and implied meaning of each information. Example Text:

The human body consists of a bony skeleton and muscles. The three main parts of the body are: the head, the trunk and the limbs (extremities). The head is composed of the cranial and facial parts. It contains the brain, the centre of the nervous system. The cranium is partly covered with hair. The parts of the face are the forehead, the temples, the ears, the eyes with eyebrows, the cheeks, the nose, the jaw, the mouth and the chin. The main parts of the mouth are lips, the tongue, the teeth, the palate and the gums. The eyes are protected by eyelids and eyelashes. The eyes are the organs of sight. The nose of smell, and the ears are the organs of hearing. The nerves of the skin are organs of touch. The five senses are: sight, hearing, smell, taste and touch. The head is attached to the trunk by the neck. The trunk includes the chest (in front), the back, the shoulders and the abdomen. The internal organs which we cannot see, are the heart, the lungs, the stomach, the liver with the gall-bladder, the pancreas, the spleen, the kidneys and the small and large intestines (bowels). The arms and legs are called the limbs. The upper extremity (arm) consists of the upper arm, the elbow, the forearm, the wrist and the hand with four fingers and one thumb. The inner side of the hand is called the palm. The finger nails protect the finger tips. The lower extremity (leg) is attached to the pelvic girdle. It is composed of the thigh, the knee with patella, the shin, the calf, the ankle and the foot. Each foot has a heel, a sole and five toes. The movement of the body is produced by the expansion and contraction of the muscles. The muscles are connected with the bones by sinews, the bones are bound together by ligaments. Organs of the body are positioned within spaces called cavities. There are these cavities in the human body: cranial, spinal, thoracic, abdominal and pelvic. 


\section{Learning Motivation}

Sardiman (2004) states that learning motivation is a non-intellectual psychological factor. Need to grow passion, feel happy, and excited to learn. The selection of the right teaching method can be a measure of the training participants' motivation. Training participants who are professional educators who have entered the age of forty and above have special learning needs and motivations. The steps that have been taken to increase the learning motivation of the training participants are:

\section{Make active participants.}

By applying the Drilling method, the training participants will begin to be active in various activities. This technique can arouse the enthusiasm for learning of the training participants in receiving the teaching material provided. In Nana Sudjana's book, the drill method is an activity of doing the same thing, repeatedly in earnest with the aim of perfecting a skill so that it becomes permanent. The distinctive feature of this method is the activity in the form of repeated repetitions of the same thing. group work techniques. Two techniques in drilling methods that are appropriate to use are group work techniques and micro teaching techniques. Group work techniques are carried out by teaching a group of students to work together in solving problems by doing the assigned assignments. While the Micro Teaching Technique is used to prepare students as prospective teachers to face teaching work in front of the class by obtaining the value of knowledge, skills and attitudes as a teacher (Sudjana, 1991)

\section{Creating a flexible learning atmosphere.}

The learning atmosphere that is applied in teaching has a strong impact on the learning motivation of the trainees. Providing a flexible atmosphere in communicating and not directly blaming is an effective technique in increasing the confidence of trainees. The training participants can give examples of phrases or sentences based on their understanding, if there is an error it will be concluded and clarified at the end of the meeting. So that the trainees' self-confidence will appear immediately and will always continue to try.

\section{Give a proportionate task.}

Do not give training participants too heavy a workload. Knowing the extent of their understanding of the material given and giving assignments according to their abilities.

\section{Understanding each individual.}

Approach the training participants so that they can understand any difficulties they face. Always pay attention to the advantages and disadvantages that are owned. In the learning process, the teacher provides clear comments and does not offend the training participants so that participants can immediately correct mistakes made.

\section{Provide tips for success in communication}

Provide instructions to training participants about the learning process being carried out. Delivering tips for success and how to get that success.

\section{Enthusiasm in teaching.}

The enthusiasm of a teacher in teaching is an important factor in motivating the training participants. Teachers must be enthusiastic and enthusiastic in delivering training participants' material. 


\section{Evaluation and Assessment}

After training for six months, it was found that four English language skills of teachers in SMP Angkasa increased significantly. Below is shown the increase in educators' assessment in the four English skills.

Tabel 2. Evaluation Score

\begin{tabular}{|c|c|c|c|c|}
\hline No & Name & $\begin{array}{c}\text { Pree-test } \\
\text { (LISTENING) }\end{array}$ & $\begin{array}{c}\text { Post-Test } 1 \\
\text { (LISTENING) }\end{array}$ & $\begin{array}{c}\text { Post-Test } 2 \\
\text { (LISTENING) }\end{array}$ \\
\hline 1 & Haerudin & 50 & 70 & 84 \\
\hline 2 & $\begin{array}{l}\text { I Ketut Bayu Agus } \\
\text { C.K }\end{array}$ & 56 & 74 & 86 \\
\hline 3 & I Made Suriadi & 52 & 70 & 88 \\
\hline 4 & $\begin{array}{l}\text { I Nyoman Putra } \\
\text { Wijaya }\end{array}$ & 40 & 68 & 84 \\
\hline 5 & $\begin{array}{l}\text { I Putu Agus Darma } \\
\text { Putra }\end{array}$ & 70 & 80 & 90 \\
\hline 6 & Luh Ratnawati & 54 & 68 & 84 \\
\hline 7 & Made Sanela Vindia & 60 & 70 & 86 \\
\hline 8 & Ni Kadek Dwi Nariani & 56 & 68 & 86 \\
\hline 9 & $\begin{array}{l}\text { NI MADE } \\
\text { PRILASARI }\end{array}$ & 60 & 70 & 86 \\
\hline 10 & Ni Made Suardani & 64 & 70 & 86 \\
\hline 11 & $\begin{array}{l}\text { Ni Wayan Novi } \\
\text { Juniasih }\end{array}$ & 66 & 72 & 88 \\
\hline 12 & Ni Wayan Sarini & 50 & 70 & 86 \\
\hline 13 & $\begin{array}{l}\text { Putu Dedi } \\
\text { Swadarmayasa }\end{array}$ & 54 & 70 & 86 \\
\hline & Kriteria & Cukup & Baik & Sangat Baik \\
\hline No & Name & $\begin{array}{c}\text { Pree-test } \\
\text { (SPEAKING) }\end{array}$ & $\begin{array}{c}\text { Post-Test } 1 \\
\text { (SPEAKING) }\end{array}$ & $\begin{array}{c}\text { Post-Test } 2 \\
\text { (SPEAKING) }\end{array}$ \\
\hline 1 & Haerudin & 66 & 71 & 85 \\
\hline 2 & $\begin{array}{l}\text { I Ketut Bayu Agus } \\
\text { C.K }\end{array}$ & 65 & 73 & 87 \\
\hline 3 & I Made Suriadi & 63 & 71 & 87 \\
\hline 4 & $\begin{array}{c}\text { I Nyoman Putra } \\
\text { Wijaya }\end{array}$ & 63 & 70 & 85 \\
\hline 5 & $\begin{array}{l}\text { I Putu Agus Darma } \\
\text { Putra }\end{array}$ & 64 & 80 & 91 \\
\hline 6 & Luh Ratnawati & 65 & 69 & 83 \\
\hline 7 & Made Sanela Vindia & 63 & 70 & 87 \\
\hline 8 & Ni Kadek Dwi Nariani & 63 & 70 & 87 \\
\hline 9 & $\begin{array}{c}\text { NI MADE } \\
\text { PRILASARI }\end{array}$ & 64 & 71 & 87 \\
\hline 10 & Ni Made Suardani & 64 & 72 & 87 \\
\hline 11 & $\begin{array}{l}\text { Ni Wayan Novi } \\
\text { Juniasih }\end{array}$ & 66 & 72 & 87 \\
\hline 12 & Ni Wayan Sarini & 66 & 71 & 85 \\
\hline 13 & Putu Dedi & 64 & 71 & 86 \\
\hline
\end{tabular}




\begin{tabular}{|c|c|c|c|c|}
\hline No & Name & $\begin{array}{c}\text { Pree-test } \\
\text { (SPEAKING) }\end{array}$ & $\begin{array}{c}\text { Post-Test } 1 \\
\text { (SPEAKING) }\end{array}$ & $\begin{array}{c}\text { Post-Test } 2 \\
\text { (SPEAKING) }\end{array}$ \\
\hline \multicolumn{5}{|c|}{ Swadarmayasa } \\
\hline & Kriteria & Cukup & Baik & Sangat Baik \\
\hline No & Name & $\begin{array}{c}\text { Pree-test } \\
\text { (READING) }\end{array}$ & $\begin{array}{l}\text { Post-Test } 1 \\
\text { (READING) }\end{array}$ & $\begin{array}{l}\text { Post-Test } 2 \\
\text { (READING) }\end{array}$ \\
\hline 1 & Haerudin & 55 & 71 & 85 \\
\hline \multicolumn{5}{|c|}{ C.K } \\
\hline 3 & I Made Suriadi & 56 & 73 & 83 \\
\hline \multicolumn{5}{|c|}{ Wijaya } \\
\hline \multicolumn{5}{|c|}{ Putra } \\
\hline 6 & Luh Ratnawati & 53 & 78 & 83 \\
\hline 7 & Made Sanela Vindia & 61 & 77 & 85 \\
\hline 8 & Ni Kadek Dwi Nariani & 56 & 75 & 85 \\
\hline \multicolumn{5}{|c|}{ PRILASARI } \\
\hline 10 & Ni Made Suardani & 63 & 71 & 85 \\
\hline \multicolumn{5}{|c|}{ Juniasih } \\
\hline 12 & Ni Wayan Sarini & 53 & 71 & 87 \\
\hline 13 & \multicolumn{4}{|l|}{ Swadarmayasa } \\
\hline & Kriteria & Cukup & Baik & Sangat Baik \\
\hline No & Name & $\begin{array}{c}\text { Pree-test } \\
\text { (WRITING) }\end{array}$ & $\begin{array}{l}\text { Post-Test } 1 \\
\text { (WRITING) }\end{array}$ & $\begin{array}{l}\text { Post-Test } 2 \\
\text { (WRITING) }\end{array}$ \\
\hline 1 & Haerudin & 53 & 73 & 85 \\
\hline 2 & \multicolumn{4}{|l|}{ C.K } \\
\hline 3 & I Made Suriadi & 53 & 72 & 87 \\
\hline \multicolumn{5}{|c|}{ Wijaya } \\
\hline \multicolumn{5}{|c|}{ Putra } \\
\hline 6 & Luh Ratnawati & 53 & 75 & 85 \\
\hline 7 & Made Sanela Vindia & 62 & 75 & 84 \\
\hline 8 & Ni Kadek Dwi Nariani & 55 & 76 & 85 \\
\hline \multicolumn{5}{|c|}{$\begin{array}{c}\text { NI MADE } \\
\text { PRILASARI }\end{array}$} \\
\hline 10 & Ni Made Suardani & 63 & 71 & 87 \\
\hline 11 & $\begin{array}{c}\text { Ni Wayan Novi } \\
\text { Juniasih }\end{array}$ & 67 & 73 & 85 \\
\hline 12 & Ni Wayan Sarini & 52 & 71 & 87 \\
\hline 13 & $\begin{array}{c}\text { Putu Dedi } \\
\text { Swadarmayasa }\end{array}$ & 53 & 71 & 87 \\
\hline & Kriteria & Cukup & Baik & Sangat Baik \\
\hline
\end{tabular}


Based on the final assessment table obtained, it can be reported that educators have mastered the material and English skills that have been taught well. Educators practice all material well during the training. Of the thirteen educators who attended the training, $76 \%$ were able to get very good criteria, and the remaining $24 \%$ received a final assessment with good criteria. So that the English training which has been carried out for six months has been able to improve four English skills of educators. Based on the results of the assessment that has been carried out, it can be reported that there has been a significant increase in the ability of educators in the four skills that have been learned. In the ability of listening skills, there was an increase in understanding by $53 \%$ from the initial pre-test to the post-test. Then in speaking skills increased by $34 \%$. In reading and writing activities, there was a significant increase of $45 \%$ in reading skills and $46 \%$ in writing skills. The improvement of these four skills states that the English language training program for educators at SMP Angkasa has been successful. So, educators at SMP Angkasa can apply the English language skills they have learned to teach in foreign languages in various disciplines.

\section{Conclusion}

From the English training given to educators at SMP Angkasa, it can be seen that the progressive progress of the trainees towards the use of English for oral and written communication. The progress in communication is evidenced by the use of English when delivering material in class. Furthermore, the ability to listen to the simple spoken conversations of the trainees has also increased, which can be seen during the training. Teachers use full English as the language of instruction during training and trainees can carry out the instructions given at that time well. Finally, there is progress in the ability to read and write simple information from the trainees. This is evidenced by the teaching material prepared by the training participants which is compiled in English and then discussed with the students in their respective classes also in the language of instruction is English. Teaching that focuses on the mastery of vocabulary, general grammar knowledge, and motivational stimulus in applying English to classroom learning is very effective for educators at SMP ANGKASA and can be applied to classroom learning according to the subject being taught.

\section{References}

Downing, A. (2015). DOWNING, Angela. English Grammar_ A University CourseRoutledge (2015).

Masruroh, L., Ainiyah, M., \& Hidayah, B. (2018). Pelatihan Pengajaran Bahasa Inggris Usia Dini bagi Guru-Guru Bahasa Inggris di PAUD-TK-MI. JPP IPTEK (Jurnal Pengabdian Dan Penerapan IPTEK), 2(1), 33. https://doi.org/10.31284/j.jppiptek.2018.v2i1.247

Nurdiana, A., \& Rahmawati, F. (2016). Adiguna: Jurnal Pengabdian dan Pemberdayaan Masyarakat http://jurnal.stkippgribl.ac.id/index.php/adiguna.

Putri. (2019). Pelatihan Public Speaking Bagi Pemandu Wisata di Bali. 2(1), 105-111.

Quirk, R., \& Svartvik, J. (1982). A University Grammar of English (book) . Longman.

Sudjana, N. (1991). Dasar-dasar Proses Belajar Mengajar. Sinar Baru.

Susilofy. (2010). Hakikat Belajar.

Swan, M. (2007). Cambridge Grammar of English. In ELT Journal (Vol. 61, Issue 1). https://doi.org/10.1093/elt/ccl048

Widarwati. (2008). Pelatihan Bahasa Inggris Bagi Guru Tk Di Kalurahan Dukuh, Kecamatan Mojolaban Sukoharjo. Journal of Chemical Information and Modeling, 53(9), 578583. https://doi.org/10.1017/CBO9781107415324.004 